\title{
Addition of Foam Agent Using Polyester and Polystyrene Waste for Lightweight Mixed
}

\author{
Safrin $Z^{1}$, Bambang $S^{2}$, Budi $H^{3}$, Wisnu $A^{4}$, Riky Sim ${ }^{5}$ \\ \{safrin.zuraidah@unitomo.ac.id $\left.{ }^{1}\right\}$ \\ 1,2,3,4,5Teknik Sipil, Fakultas Teknik, Universitas Dr.Soetomo, Indonesia
}

\begin{abstract}
The development of the Indonesian industry has made considerable progress, which has had a positive impact on the country's economy. In addition to the increasingly rapid success of the industry, the negative impacts are more and more waste generated by the Indonesian industry, such as fiber strapping bands and polystyrene waste that is difficult to break down. This encourages researchers to be able to manage waste results, so that they can be reused without polluting the environment, for example by converting fiber strips into waste and polystyrene into a mix of materials for the manufacture of light bricks. The characteristics of lightweight polystyrene tapes and fibrous fiber strapping bands are suitable for use in the form of lightweight brick mixes to reduce the weight of lightweight bricks to make them lighter without reducing compressive strength or strength. to traction. In general, the weight of lightweight brick varies from $600 \mathrm{~kg} / \mathrm{m} 3$ to $1800 \mathrm{~kg} / \mathrm{m} 3$, so that research is carried out by adding polystyrene to $20 \%$ of the cylinder volume and adding fiber strapping bands. two sizes, namely $30 \mathrm{~mm}$ and $40 \mathrm{~mm}$ in variation $0 \%, 2 \%, 4 \%, 6 \%$ of the weight of cement. Dr. Soetomo Surabaya says that the higher the percentage of polyester, the higher the compressive strength and tensile strength produced, University trials have shown. These results are inversely proportional to the weight of the light brick volume indicated by the increase in the number of strapping bands, further decreasing the weight of the lightweight brick to conform to the Indonesian National Standard for Lightweight Brick. The optimum polyester content is $6 \% 30 \mathrm{~mm}$ polyester fiber, giving a maximum compressive strength of $3208 \mathrm{MPa}$ $(142.85 \%)$ with a tensile strength of $0.54 \mathrm{MPa}(63.64 \mathrm{~mm}) . \%)$ and a decrease in weight to $1250 \mathrm{~kg} / \mathrm{m} 3(7.75 \%)$.
\end{abstract}

Keywords: Lightweight Brick, Polyester, compressive strength, split tensile.

\section{Introduction}

Major industrial developments in Indonesia have boosted the country's economy. The success of the industry is growing faster, with negative consequences, including the problem of waste produced by industries such as polyester waste and polystyrene waste, which are made from plastic that is difficult to break down the soil. Various efforts in the use of this waste are one of them in the strapping band of waste. Relatively new polyester wastes are usually recycled into handicrafts, while collectors do not collect the damaged waste because they have a relatively cheap market value and take up storage space. This encourages researchers to be able to manage waste results so that they can be used in ways that increase their economic value and reduce environmental pollution by creating polyester fiber waste and waste. Polystyrene waste as a mixture of light. bricks. Lightweight brick is a revolutionary alternative technology to replace red bricks and concrete blocks consisting of a mixture or content of materials consisting of silica sand, cement, water, substances addictive to foaming 
agents ( chemical air charge). As a general rule, the weight of lightweight bricks ranges from $600 \mathrm{~kg} / \mathrm{m} 3$ to $1800 \mathrm{~kg} / \mathrm{m} 3$; one of the advantages of lightweight brick is, therefore, its lighter weight than that of a normal brick, which has a density ranging from $1700 \mathrm{~kg} / \mathrm{m} 3$ to $1900 \mathrm{~kg}$. / m3 [1] On the other hand, the strength of this brick has a compressive strength of between $1 \mathrm{MPa}$ and $15 \mathrm{MPa}$ (Andres, 1989). Lightweight bricks used in high-rise buildings will significantly reduce the load on the building's main structure, which will affect the calculation of foundations. reduce the weight of light light brick without reducing the compressive strength, the strong pull of the brick itself.

\subsection{Lightweight Concrete}

Concrete is a mixture of Portland cement or other hydraulic cement, fine aggregates, coarse aggregates, and water, with or without additives, forming solid periods [2], [3]. Normal concrete is a relatively heavy building material with a density of 2.4 or weight of $2400 \mathrm{~kg} /$ $\mathrm{m} 3$. To reduce the permanent load of a concrete structure, lightweight concrete bricks were used. According to SNI 03-2847-2002, lightweight concrete is concrete containing light aggregates with a unit weight not exceeding $1900 \mathrm{~kg} / \mathrm{m} 3$. Lightweight concrete is obtained by adding air pores to the concrete mix.

\subsection{State of the Art}

According to the results of several previous studies on lightweight concrete, said that:

The optimal increase occurred at polypropylene levels of $0.75 \%$ of the concrete volume weight with a compressive strength of $18.38 \mathrm{MPa}$ and a divided tensile strength of 2.69 MPa.[4], according to the results of the next study, indicates that the optimal increase occurs with a polyester content of $0.75 \%$ of the concrete volume weight with a compressive strength of 12.20 MPa and a divided tensile strength of $2.88 \mathrm{MPa}$. [5], at the time of the research, the highest average compressive strength was obtained with light bricks containing $0.61 / \mathrm{m} 3$ of foaming agent with 4.02 MPa quartz sand, heavy section divided with a foaming agent of 0.61 / $\mathrm{m} 3$ with a working sand of $0.34 \mathrm{MPa}$, flexural strength of concrete beams with a foam content of $0.61 / \mathrm{m} 3$ with a sand working pressure of $0.738 \mathrm{MPa}$. [6]continued his research on the manufacture of lightweight bricks with silica sand and white cement from the silica sand content ratio of $0 \%, 25 \%, 50 \%, 75 \%, 100 \%$ for obtain the optimum value of $50 \%$ silica sand with a foaming agent content of $0.4 \mathrm{lt} / \mathrm{m} 3$ with a maximum compressive strength of 2.83 $\mathrm{MPa}$. And the optimal $50 \%$ silica sand, with a maximum breaking strength at 28 days, is 0.353 MPa. [7]

\section{Composite materials and additional materials}

The ingredients used for the blending consist of cement, fine aggregates, coarse aggregates, water, and additives. When planning, a mix of materials must meet the requirements.

\subsection{Portland cement}

The function of cement is to bind the aggregate grains into a single solid. Cement, when mixed with water, forms a paste and when mixed with sand and water, it becomes a cement mortar.Agregat Halus (Pasir Mojokerto dan Pasir Silika) 


\subsection{The fine granulate}

is a sand-shaped filler, an aggregate consisting of sharp, hard grains. Fine aggregate pearls must be eternal, that is, they are neither broken nor destroyed by meteorological factors such as sun and rain (Istimawan Dipohusodo, 1999).

\subsection{Water}

According to SNI 03-2847-2002, the requirements for water that can be used for the manufacture of concrete are as follows: clean, free of oil and salt.

\subsection{Admixture}

are materials or materials other than water, cement, and aggregates added to the concrete or mortar before or during agitation that are used to modify the properties and characteristics of the concrete and mortar at your leisure. In this study, the additional materials used are:

a. FiberPolyester. The addition of plastic fibers has the advantage of reducing the formation of cracks due to shrinkage and shrinkage, in particular by increasing the tensile stress capacity on lightweight bricks.

b. Polystyrene. The use of polystyrene in lightweight bricks can be considered as an air cavity. But the advantage of polystyrene over the use of lightweight brick cavities is that it has tensile strength. Thus, in addition to lightening the concrete, it can also function as a tensioned fiber, increasing the strength and in particular the ductility of the concrete.

c. Foam Agent. The foaming agent is an ingredient added in the form of additives to be mixed in concrete mortar. The concentrated foam produced during mixing and agitation in the concrete mortar, the concrete volume increases, and the density decreases because it forms an air cavity in the concrete.

\subsection{Lightweight Brick Strength}

a. compressive strength. The compressive strength is a parameter that indicates the magnitude of a load of a large unit that causes the object to be tested to be destroyed by a certain compressive force.

b. Split tensile strength. The tensile strength of concrete obtained by cylindrical tensile tests is achieved by applying a uniform compressive load over the entire length of the bottle to divide it end-to-end.

\section{Research methodology}

\subsubsection{Research Diagram}

The stages of this study are as follows:

\subsubsection{Press the strength test}

This test is performed to determine the compressive strength of concrete that has hardened with a cylindrical sample. Loading is carried out until the concrete cylinder is destroyed and the maximum load size of $\mathrm{P}$ is recorded, which is then used to determine the compressive stress of the concrete ( $\left.\mathrm{f}^{\prime} \mathrm{c}\right)$.

Can be written with equations (SNI 1974-2011): 


$$
f^{\prime} c=\frac{P}{A}
$$

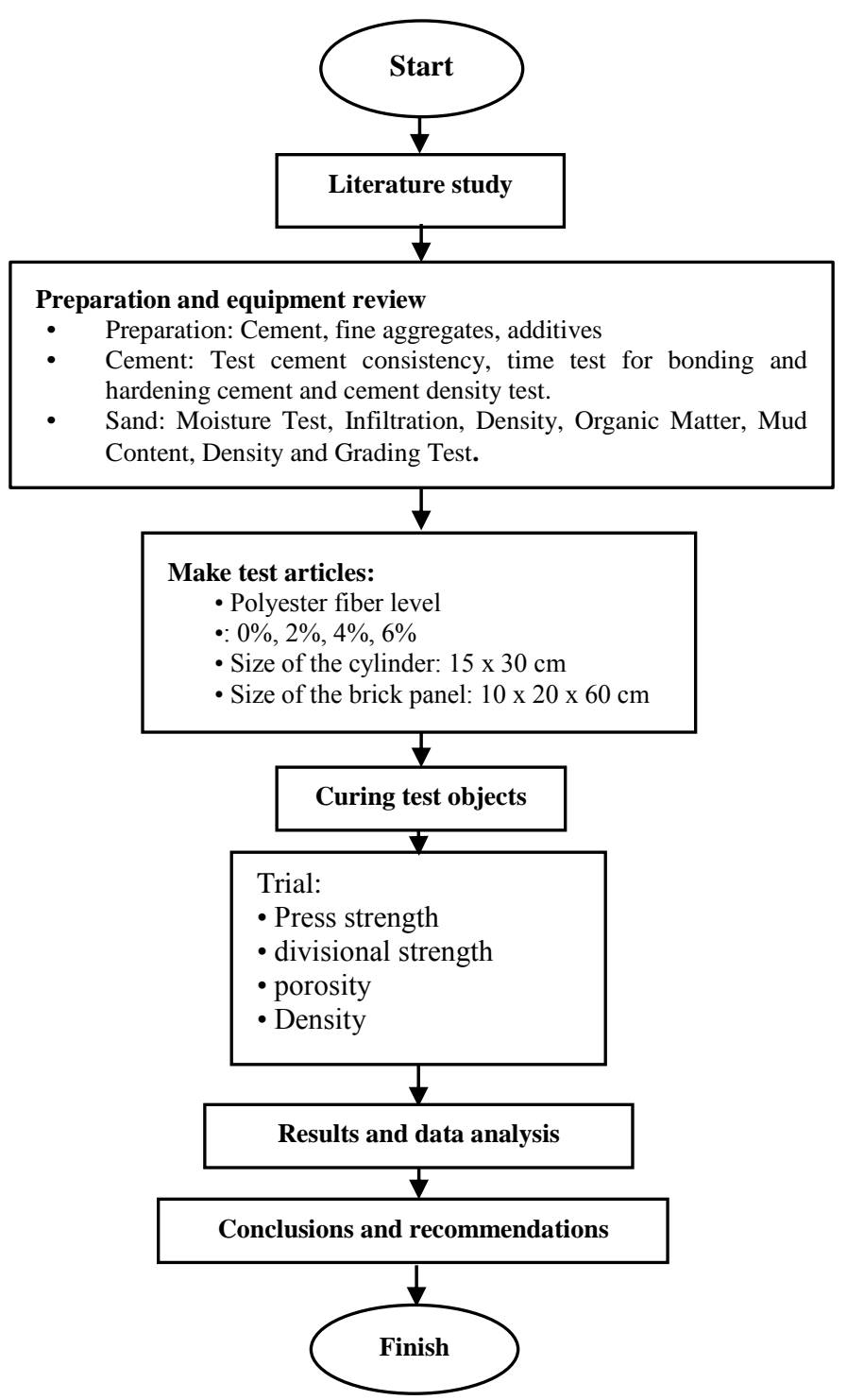

Fig. 1. Research Flowchart

\subsubsection{Tensile strength test}

This test is performed by applying indirect tensile stress on the concrete. The test object used is in the form of a cylinder which is stretched and pressed. The steps of the test are identical to those of the compressive strength test, except for this test, that is to say of the 
fixing plate. The maximum load is then used to determine the tensile stress of the concrete (fct).

The cylindrical tensile strength can be determined by the equation (SNI 03-2491-2002):

$$
\mathrm{fct}=\frac{2 \mathrm{P}}{\pi \mathrm{LD}}
$$

\subsubsection{Porosity test}

The porosity test procedure is performed to determine the amount of porosity found in the object to be tested. The greater the porosity of the object to be tested, the lower the resistance, and vice versa. The porosity test is carried out on cylindrical specimens $5 \mathrm{~cm}$ in diameter and $10 \mathrm{~cm}$ in height at 28 days. The calculation of the porosity can be done using the formula:

$$
\text { Porositas }=\frac{\mathrm{mb}-\mathrm{mk}}{\mathrm{Vb}} \times \frac{1}{\rho \mathrm{air}} \times 100 \%
$$

That:

$$
\begin{array}{ll}
\mathrm{m}_{\mathrm{b}} & =\text { Wet weight } \\
\mathrm{m}_{\mathrm{k}} & =\text { dry weight } \\
\mathrm{V}_{\mathrm{b}} & =\text { Volume } \\
\rho_{\text {air }} & =\text { Type of water body }
\end{array}
$$

\subsubsection{The test of density}

The test of the density of light bricks is a comparison between the weight of the light brick and its volume. In thic ctury, the test of the density of light bricks at the age of 28 days. Using the formula as : $\boldsymbol{\gamma}=\frac{\boldsymbol{\omega}}{\boldsymbol{v}}$

That :
$\gamma$ : Density $\left(\mathrm{kg} / \mathrm{m}^{3)}\right.$
$\omega$ : Weight of concrete specimens $(\mathrm{kg})$
$\mathrm{v}$ : volume $\left(\mathrm{m}^{3)}\right.$

\section{Result and data analysis}

Table 1. Test Results Density Age 28 Days

\begin{tabular}{ccc}
\hline Length & Variasi $S B(\%)$ & Average Density $\left(\mathrm{kg} / \mathrm{m}^{3}\right)$ \\
\hline \multirow{3}{*}{$30 \mathrm{~mm}$} & 0 & 1355 \\
& 2 & 1323 \\
& 4 & 1304 \\
$40 \mathrm{~mm}$ & 6 & 1250 \\
& 0 & 1355 \\
& 2 & 1319 \\
& 4 & 1275 \\
& 6 & 1247 \\
\hline
\end{tabular}




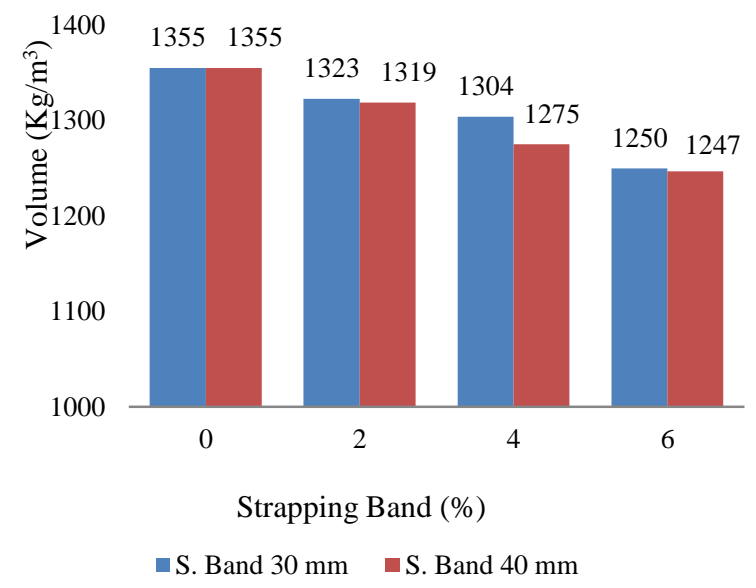

Fig. 2. Diagram of the relationship weight in volume with the level and size of the polyester fiber

Based on the results of the summary of the relationship diagram in Fig. 2, it can be concluded that the increased use of polyester fibers in light brick mixes reduces the lightweight volume of lighter bricks as well as the size of the bricks. longer light bricks. strapping bands. Lightweight brick with $0 \%$ polyester is known to be heavier than brick which uses fiber strapping, so the addition of Polyester is considered to be suitable for reducing the weight of light brick volume. $30 \mathrm{~mm}$ decreased with a weight of $1250 \mathrm{~kg} / \mathrm{m} 3$ and Poly $6 \%$ with a size of $40 \mathrm{~mm}$ decreased with a weight in volume of $1247 \mathrm{~kg} / \mathrm{m} 3$, so that the weight in volume can be classified in the category of bricks light because it is less than $1800 \mathrm{~kg} / \mathrm{m} 3$. [8]

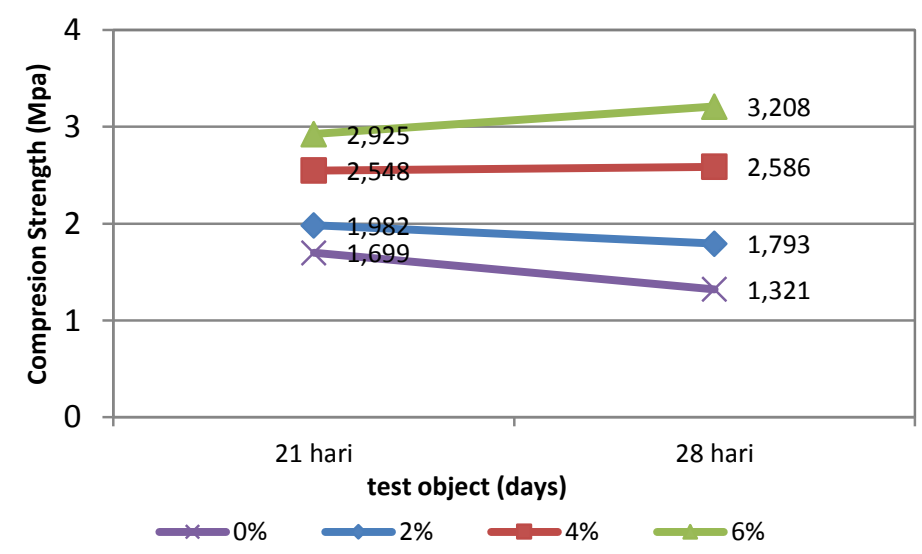

Fig. 3. Graph of the relationship between average compressive strength and age of concrete at 21 and 28 days on a $30 \mathrm{~mm}$ long polyester fiber 
According to Figure 3, the addition of polyester fibers to the light brick mix can increase the compressive strength of lightweight bricks. Test results show that on a 28 -day lightweight brick with a $2 \%$ polyester content, the compressive strength increased by $0.472 \mathrm{MPa}(35.73 \%)$, the polyester content by $4 \%$ increased by $1,265 \mathrm{MPa}(95.76 \%)$ and $6 \%$ experienced an increase in compressive strength of $1,887 \mathrm{MPa}(142.85 \%)$.

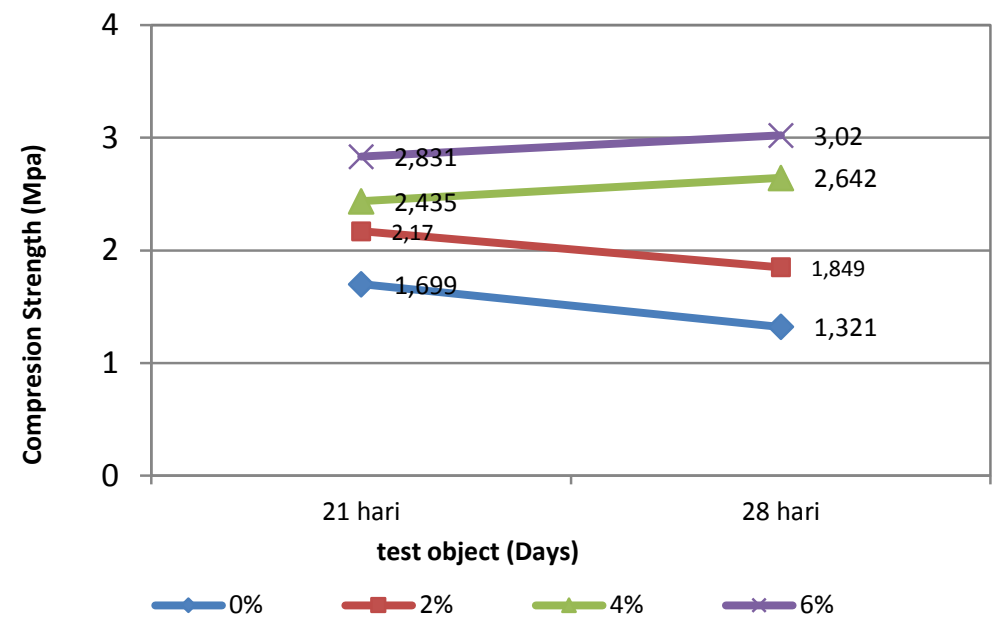

Fig. 4. Graph of the relation between the average resistance of the press and the concrete of the ages 21 and 28 days in PF Length $30 \mathrm{~mm}$

From Figure 4, the addition of polyester fibers to the light brick mix can increase the compressive strength of lightweight bricks. Test results show that on 28-day lightweight bricks containing $2 \%$ polyester, the compressive strength increased by $0.528 \mathrm{MPa}(39.97 \%)$, the polyester content $4 \%$ increased by $1.321 \mathrm{MPa}(100 \%)$ and at the polyester level. $6 \%$ increase in compressive strength from $1.699 \mathrm{MPa}(128.61 \%)$.

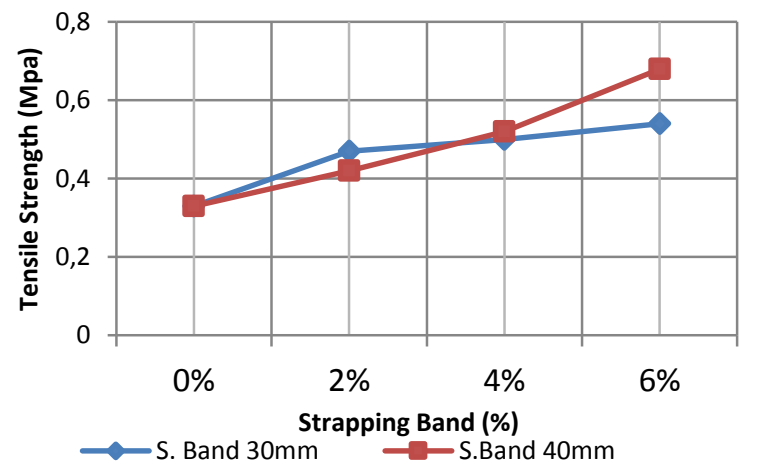

Fig. 5. Graph of the relationship between average tensile strength and age of concrete at 28 days on a $40 \mathrm{~mm}$ and $30 \mathrm{~mm}$ long polyester fiber 
According to Figure 5, the addition of polyester fibers to the light brick mix can increase the tensile strength of lightweight bricks. Test results show that on 28-day lightweight bricks with a polyester content of $2 \%, 4 \%$, and $6 \%$, the size of $30 \mathrm{~mm}$ shows an increase in tensile strength in a row of $0.14 \mathrm{MPa}(42.42 \%), 0.17 \mathrm{MPa}(51.52 \%)$ and $0.21 \mathrm{MPa}(63.64 \%)$, the same thing on the $40 \mathrm{~mm}$ polyester experienced an increase in the tensile strength of $0.09 \mathrm{Mpa}(27.27 \%)$, $0.19 \mathrm{Mpa}(57.58 \%)$ and $0.35 \mathrm{Mpa}(106.06 \%)$

Tabel 2. Relationship between compression force and split force at 28 days

\begin{tabular}{ccccc}
\hline $\begin{array}{c}\text { Variasi } \\
\begin{array}{c}\text { Strapping } \\
\text { band } \\
(\%)\end{array}\end{array}$ & $\begin{array}{c}\text { Size of } \\
\text { Strapping } \\
\text { band } \\
(\mathrm{mm})\end{array}$ & $\begin{array}{c}\text { Tensile } \\
\text { Strength } \\
\left(\mathrm{f}^{\prime} \mathrm{ct}\right)(\mathrm{Mpa})\end{array}$ & $\begin{array}{c}\text { Compression } \\
\text { Strength }\left(\mathrm{f}_{\mathrm{c}}\right)\end{array}$ & $\begin{array}{c}\text { Rasio } \\
(\mathrm{Mpa})\end{array}$ \\
\hline 0 & & 0,33 & 1,321 & 0,29 \\
2 & 30 & 0,47 & 1,793 & 0,35 \\
4 & & 0,50 & 2,586 & 0,31 \\
6 & & 0,54 & 3,208 & 0,30 \\
0 & & 0,33 & 1,321 & 0,29 \\
2 & 40 & 0,42 & 1,849 & 0,31 \\
4 & & 0,52 & 2,642 & 0,32 \\
6 & & 0,68 & 3,020 & 0,39 \\
\hline
\end{tabular}

From Table 2, the results of the relationship between the value of the compressive strength and the value of the divided tensile strength obtained from this study are different from the relationship between the divided tensile strength and compressive strength according to SNI T-15-1991. The SNI T-15-1991 indicates that $\mathrm{ft}=0.7 \sqrt{ }(\mathrm{f} \mathrm{c})$, because these research mixtures do not use pumice (broken stone), of course, the results of the research are smaller.

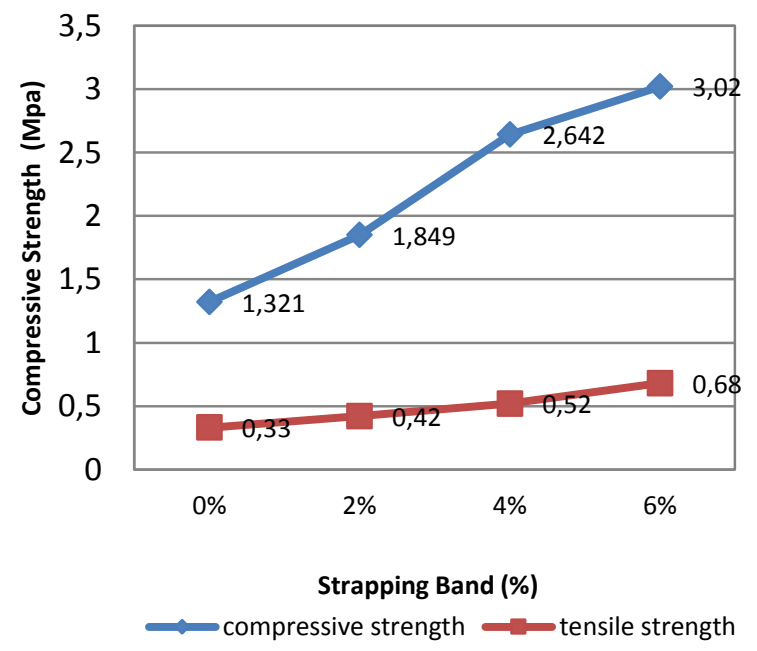

Fig. 6. Graphical relationship of compressive strength and average tensile strength at 28 days of size $30 \mathrm{~mm}$ 
On the basis of FIG. 6, the comparison between the compressive strength and the attractiveness of the light brick shows that the more the number of polyester fibers used increases, the more the mixture of light bricks increases the compressive strength and the tensile strength of light brick. It can be seen that each addition of Polyesthesia resulted in a significant increase in compressive strength at the maximum conditions at the $6 \%$ polyester levels, while in the case of tensile strength a significant increase did not occur. only at polyester levels of $2 \%$, after which the increase was lower than $6 \%$ maximum condition.

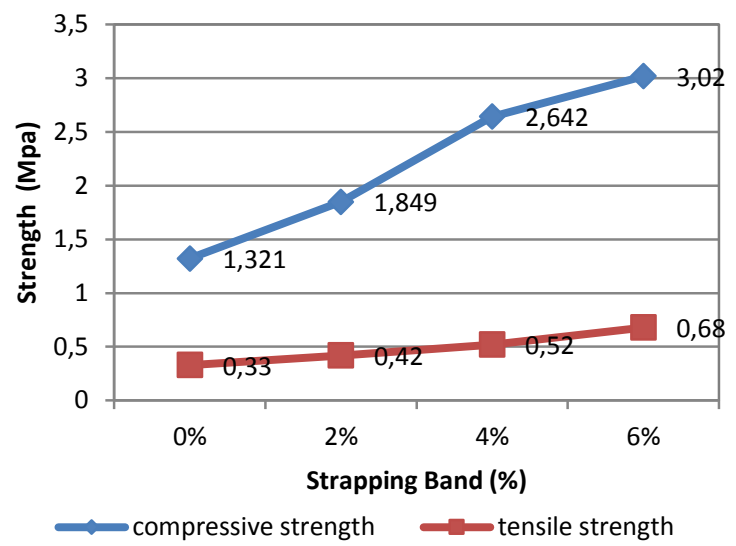

Fig. 7. Graphical relationship of compressive strength and average tensile strength at 28 days of size $40 \mathrm{~mm}$

On the basis of Figure 7, the comparison between compressive strength and light brick tensile strength shows that as the number of polyester fibers used increases, so does the light brick mix to increase compressive strength and strength. to the pull of the light brick. It can be seen in each addition of polyesthesia that has a significant increase in compressive strength and divided tensile strength at the maximum conditions of Polyester\% $6 \%$.

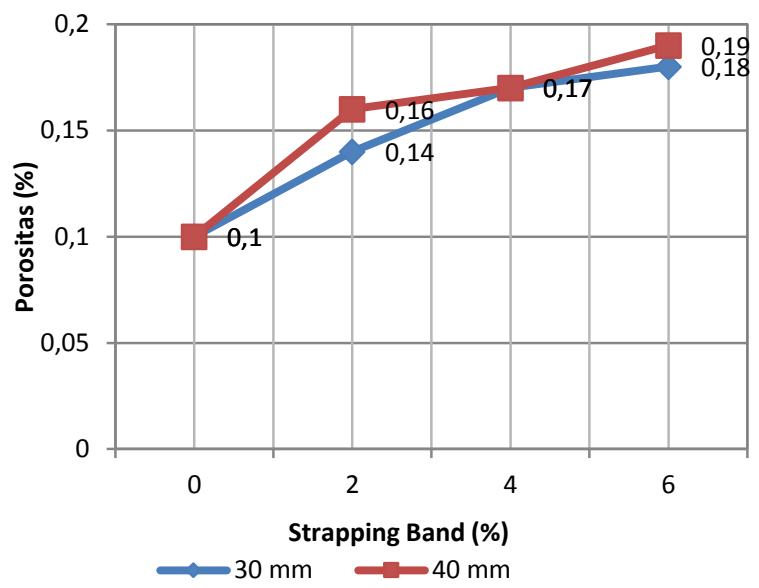

Fig. 8. Graph of the relationship between the polyester level and the porosity of the light brick 
Graph 8 shows that the higher the level of polyester in the light brick, the greater the porosity that occurs in the light brick. The increase in porosity is due to the irregular position of the groove of the fiber and the polystyrene which contracts because of the passage in the oven so that it leaves the cavity because it is not filled with mortar. Table 4.28 shows increasing polyester porosity increase of $2 \mathrm{~mm}, 4 \%$ and $6 \%$ in a row of $0.14 \%, 0.17 \%$ and $0.18 \%$ for the $30 \mathrm{~mm}$ polyester, as well as for the polyester $40 \mathrm{~mm}$. the addition of $2 \%, 4 \%$ and $6 \%$ polyester increased the porosity by $0.16 \%, 0.17 \%$ and $0.19 \%$ respectively.

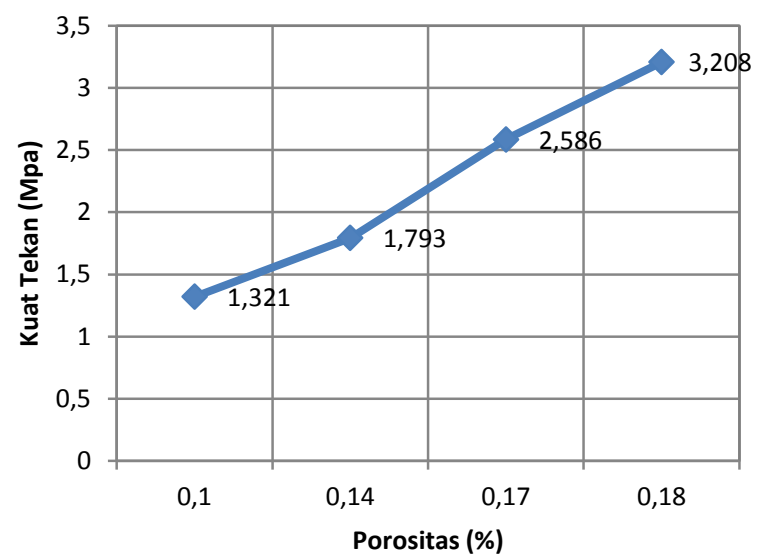

Fig. 9. Graph of Porosity Relations with Light Brick-Force Polyester Size 30mm to 28 Days

From Figure 9, it can be seen that when the light brick porosity of $0.14 \%$ increased the compressive strength of $0.472 \mathrm{MPa}(35.73 \%)$, when the porosity of the light brick is $0,17 \%$, increased by $1.265 \mathrm{MPa}(95.76 \%)$ and increased until the light brick porosity of $0.18 \%$ had an increased compressive strength of $1.887 \mathrm{MPa}(142.85 \%)$.

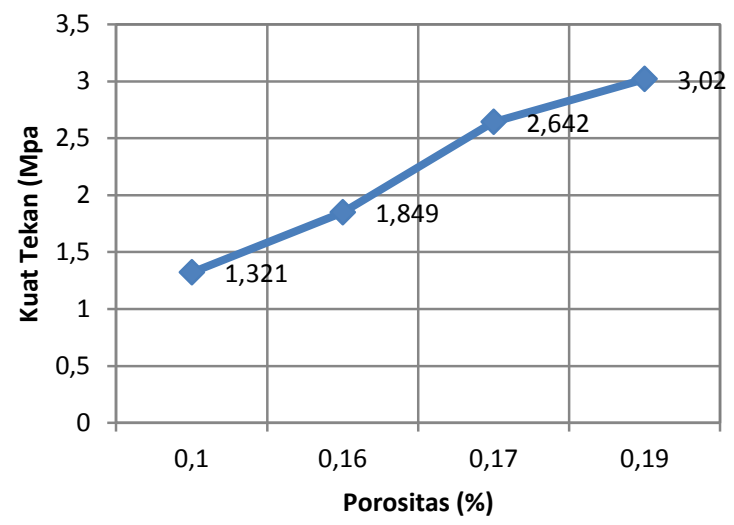

Fig. 10. Graph of the porosity relationship with the compressive strength polyester weight of light brick, $40 \mathrm{~mm}$, at 28 days 
From Figure 10, it can be seen that when the porosity of the light brick of $0.16 \%$ increased the compressive strength of $0.528 \mathrm{MPa}(39.97 \%)$, when the porosity of the light brick was $0,17 \%$, it increased by $1.321 \mathrm{MPa}(100 \%)$, and the increase continued to increase until the light brick porosity of $0.19 \%$ increases the compressive strength of $1.699 \mathrm{MPa}(128.61 \%)$.

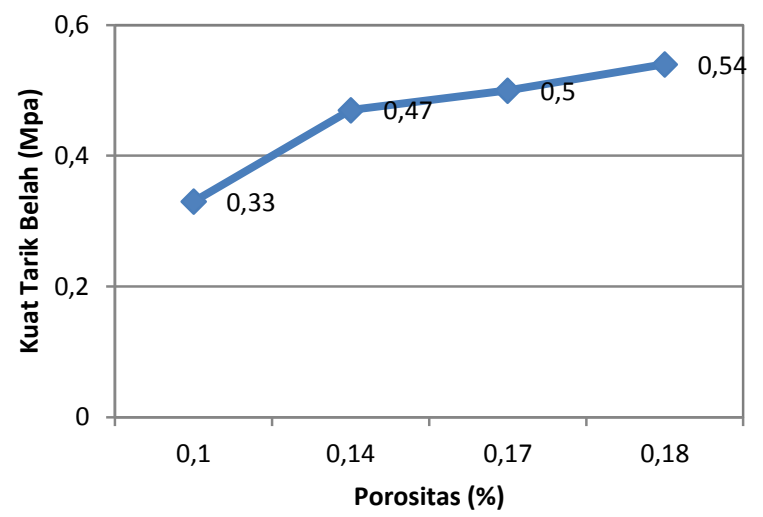

Fig. 11. Graph of the relationship between porosity and tensile strength polyester for a lightweight brick slab, size $30 \mathrm{~mm}$ to 28 days

From Figure 11 it can be seen that when the light brick porosity increased by $0.14 \mathrm{MPa}$ $(42.42 \%)$, the light brick tensile strength increased by $0.17 \%$. 51.52\%) and the increase continues to increase until the porosity of the light brick of $0.18 \%$ increases the tensile strength by $0.21 \mathrm{MPa}(63.64 \%)$.

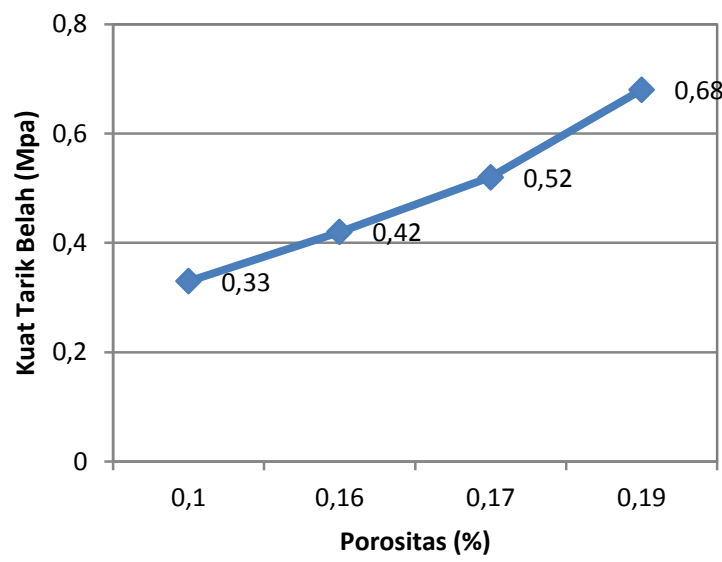

Fig. 12. Graph of porosity relationships with the light drag strength of a lightweight brick, polyester size $40 \mathrm{~mm}$ to 28 days

From Figure 19, it can be seen that at the moment of light porosity of the brick $0.16 \%$, $0.17 \%$ and $0.19 \%$, the increase in tensile strength was $0.09 . \mathrm{MPa}(27.27 \%)$ and $0.19 \mathrm{MPa}(57$, respectively). 58\%) and $0.35 \mathrm{MPa}(106.06 \%)$. 
Table 3. Summary of test results for the 28-day lightweight brick

\begin{tabular}{cccccc}
\hline $\begin{array}{c}\text { Strapping } \\
\text { Band } \\
(\%)\end{array}$ & $\begin{array}{c}\text { Size of } \\
\text { S.Band } \\
(\mathrm{mm})\end{array}$ & $\begin{array}{c}\text { Compressive } \\
\text { Strength }(\mathrm{Mpa})\end{array}$ & $\begin{array}{c}\text { Tensile } \\
\text { Strength } \\
(\mathrm{Mpa})\end{array}$ & $\begin{array}{c}\text { Porositas } \\
(\%)\end{array}$ & $\begin{array}{c}\text { Volume } \\
\left(\mathrm{Kg} / \mathrm{m}^{3}\right)\end{array}$ \\
\hline 0 & & 1,321 & 0,33 & 0,10 & 1355 \\
2 & \multirow{2}{*}{30} & 1,793 & 0,47 & 0,14 & 1323 \\
4 & & 2,586 & 0,50 & 0,17 & 1304 \\
6 & & 3,208 & 0,54 & 0,18 & 1250 \\
0 & & 1,321 & 0,33 & 0,10 & 1355 \\
2 & \multirow{2}{*}{40} & 1,849 & 0,42 & 0,16 & 1319 \\
4 & & 2,642 & 0,52 & 0,17 & 1275 \\
6 & & 3,020 & 0,68 & 0,19 & 1247 \\
\hline
\end{tabular}

From Table 3, it can be concluded that the optimal conditions of use of variations and sizes of Polyesthesia produce the maximum compressive strength and tensile strength, and reach the category of light volume bricks, to know Polyester $30 \mathrm{~mm}$ under optimal conditions. Polyester 6\% with a compressive strength of $3.308 \mathrm{MPa}$, a tensile strength of $0.54 \mathrm{MPa}$ and a density of $1250 \mathrm{~kg} / \mathrm{m} 3$, while for polyester 40 , the size is in optimal conditions Polyester $6 \%$ with a compressive strength of $3.020 \mathrm{MPa}$, a divided tensile strength of $0.68 \mathrm{MPa}$ and a density of $1247 \mathrm{~kg} / \mathrm{m} 3$. Thus, on the basis of the percentage of porosity, it can be concluded that the size of the $30 \mathrm{~mm}$ polyester is considered the optimum condition because its porosity does not significantly affect the compressive strength of lightweight bricks. The difference in maximum compressive strength can be seen between the $30 \mathrm{~mm}$ polyester with a porosity percentage of $0.18 \%$ compressive strength of $3.208 \mathrm{MPa}$ and the $40 \mathrm{~mm}$ polyester with a percent porosity greater than $0.19 \%$ to achieve a lower compressive strength of $3.020 \mathrm{MPa}$. Limiting light concrete uses non-fire resistant polyester and polystyrene

\section{Conclusion}

According to the results of the study, the higher the polyester content, the more the compressive strength and the tensile strength are fractionated and inversely proportional to the weight of the volume of the light brick. The optimal state of the polyester levels has increased considerably and produces a maximum compressive strength of $3.208 \mathrm{MPa}(142.85 \%)$ and a divided tensile strength of $0.54 \mathrm{MPa}$ $(63.64 \%)$ with a reduction of the density to $1250 \mathrm{~kg} / \mathrm{m} 3(7,75 \%)$ to a size of $30 \mathrm{~mm}$ with a fiber content of $6 \%$ of the weight of cement.

\section{References}

[1] K. Tjokrodimuljo, "Teknologi beton,” Nafiri, Yogyakarta, pp. 56-57, 1996.

[2] "Self-Organizing-Maps en el estudio del concreto de alto rendimiento," Rev. ECIPeru, 2018.

[3] A. Fernanda, L. L. Cristina J, M. Siviero Guilherme, A. P. Elisabete A, R. Cristina Cecche, and L. Andréia, "Effects of Consumption of Cement in Mechanical Properties of Lightweight Concrete containing Brazilian Expanded Clay," Appl. Mech. Mater., 2013.

[4] F. Song, Y. Li, Z. Shen, Y. Hong, Z. Xie, and R. Liao, "Effect of $\mathrm{TiO}<\mathrm{inf}>2</$ inf $>$ addition amount on structure and microwave dielectric properties of $\mathrm{Zn}<\inf >0.8</ \inf >\mathrm{Mg}<\inf >0.2</ \inf >\mathrm{ZrNb}<\inf >2</ \inf >0<<\inf >8</ \inf >$ ceramic, $\quad$ Киеi 
Suan Jen Hsueh Pao/Journal Chinese Ceram. Soc., 2015.

[5] M. S. YAHYA, "PENGARUH PENAMBAHAN SERAT POLYESTER PADA BETON RINGAN DENGAN TEKNOLOGI GAS TERHADAP KUAT TEKAN, KUAT TARIK BELAH DAN MODULUS ELASTISITAS.” UNIVERSITAS SEBELAS MARET, 2015.

[6] S. Mahjoob and K. Vafai, "A synthesis of fluid and thermal transport models for metal foam heat exchangers," Int. J. Heat Mass Transf., 2008.

[7] V. R. dan A. Damayanti, "Pengolahan Limbah Cair Industri Pewarnaan Jeans Menggunakan Membran Silika Nanofiltrasi Aliran Cross Flow untuk," Tek. Pomits, 2013.

[8] M. N. Haque and O. Kayali, "Properties of high-strength concrete using a fine fly ash," Cem. Concr. Res., 1998. 